\title{
Motion prediction using electromyography and sonomyography for an individual with transhumeral limb loss
}

\author{
Susannah Engdahl ${ }^{1 \pi}$, Ananya Dhawan ${ }^{11 I}$, György Lévay $^{2}$, Ahmed Bashatah $^{1}$, Rahul Kaliki $^{2}$, \\ Siddhartha Sikdar, ${ }^{1, *}$ \\ ${ }^{1}$ Department of Bioengineering, George Mason University, Fairfax, Virginia, United States of \\ America \\ ${ }^{2}$ Infinite Biomedical Technologies, Baltimore, Maryland, United States of America \\ ${ }^{3}$ Center for Adaptive Systems of Brain-Body Interactions, George Mason University, Fairfax, \\ Virginia, United States of America
}

* Corresponding author

Email: ssikdar@gmu.edu (SS)

II These authors contributed equally to this work. 


\section{Abstract}

Controlling multi-articulated prosthetic hands with surface electromyography can be

3 challenging for users. Sonomyography, or ultrasound-based sensing of muscle deformation,

4 avoids some of the problems of electromyography and enables classification of multiple motion

5 patterns in individuals with upper limb loss. Because sonomyography has been previously

6 studied only in individuals with transradial limb loss, the purpose of this study was to assess the

7 feasibility of an individual with transhumeral limb loss using this modality for motion

8 classification. A secondary aim was to compare motion classification performance between

9 electromyography and sonomyography. A single individual with transhumeral limb loss created

10 two datasets containing 11 motions each (individual flexion of each finger, thumb abduction,

11 power grasp, key grasp, tripod, point, pinch, wrist pronation). Electromyography or

12 sonomyography signals associated with every motion were acquired and cross-validation

13 accuracy was computed for each dataset. While all motions were usually predicted successfully

14 with both electromyography and sonomyography, the cross-validation accuracies were typically

15 higher for sonomyography. Although this was an exploratory study, the results suggest that

16 controlling an upper limb prosthesis using sonomyography may be feasible for individuals with

17 transhumeral limb loss.

\section{Introduction}

Abandonment of upper limb prostheses is common [1] and is largely attributable to user

21 concerns regarding comfort and function [2,3]. In fact, one survey reported that $98 \%$ of

22 individuals who have rejected a prosthesis believe they are just as or more functional without a 
medRxiv preprint doi: https://doi.org/10.1101/2020.12.23.20248489; this version posted December 26, 2020. The copyright holder for this preprint (which was not certified by peer review) is the author/funder, who has granted medRxiv a license to display the preprint in perpetuity.

It is made available under a CC-BY-NC-ND 4.0 International license .

23 prosthesis, an opinion which is echoed by $60 \%$ of those who do wear a prosthesis frequently [2].

24 Recent research efforts have focused on developing dexterous prosthetic hands and associated

25 control strategies in an effort to improve user functionality, but the prosthetic terminal devices

26 and componentry have improved much more rapidly than the ability to control the devices. Thus,

27 robustly inferring volitional motor intent from the user remains challenging [4].

28 Conventional prosthesis control strategies rely on surface electromyography (EMG) to

29 detect muscle activation in a user's residual limb. However, surface EMG signals typically have

30 poor amplitude resolution and a low signal-to-noise ratio [5,6], as well as limited specificity

31 between muscles due to cross-talk and co-activation [7-10]. Multi-articulated prosthetic hands

32 commonly use dual-site surface EMG electrodes placed on an agonist-antagonist muscle pair in

33 order to actuate the hand using a direct control strategy. Since direct control only enables

34 opening and closing of the hand, switching between grasps must be initiated by a separate trigger

35 such as a designated EMG signal pattern (e.g., co-contraction), physical gesture, or button press.

36 These mode switching methods can be cumbersome and are strongly disliked by some users

$37[11]$.

38 In an effort to mitigate some of these problems, pattern recognition algorithms are

39 actively being developed in order to extract user intent from an array of surface EMG signals.

40 Pattern recognition has shown some functional advantages in comparison to direct control

$41[12,13]$. However, one study found no difference in function or satisfaction between the systems

42 for a two degree of freedom prosthesis [14] and others found that pattern recognition failed to

43 improve outcomes for users of multi-degree of freedom prostheses $[15,16]$. These studies

44 focused on gross wrist and hand movements, but dexterous control of individual finger

45 movements is also possible with pattern recognition [17-20]. Despite these potential advantages 
medRxiv preprint doi: https://doi.org/10.1101/2020.12.23.20248489; this version posted December 26, 2020. The copyright holder for this preprint (which was not certified by peer review) is the author/funder, who has granted medRxiv a license to display the preprint in perpetuity.

It is made available under a CC-BY-NC-ND 4.0 International license .

46 of pattern recognition, considerable training is often required for users to reliably produce the set

47 of distinct EMG patterns required for this modality [21,22].

48 Rather than controlling a prosthesis through detection of muscular electrical activity, an

49 alternative approach relies on ultrasound imaging to sense muscle deformation during voluntary

50 movement. This method, known as sonomyography (SMG), avoids many of the limitations of

51 EMG because it can spatially resolve individual muscles, even those deep inside the arm. This

52 high spatial specificity means that muscular cross-talk does not contaminate the extracted control

53 signals that can be used to drive movement of a prosthesis. Numerous studies have established

54 SMG as a viable option for gesture recognition and prosthesis control [23-26]. In particular, our

55 group has demonstrated the ability to classify five individual digit movements with 97\%

56 accuracy [27] and 15 complex grasps with $91 \%$ accuracy [28] in able-bodied individuals. There

57 has been relatively little exploration of the use of SMG in individuals with upper limb loss [29-

58 33], although we have reported an average classification accuracy of $96 \%$ for five grasps in this

59 population [32] with minimal training required [33].

However, all studies to date on individuals with upper limb loss using SMG have focused

61 on a transradial population. It is unknown whether SMG can be successfully used for motion

62 classification by individuals with more proximal limb loss. Since the muscles associated with

63 wrist, hand, and finger control are primarily located in the forearm, absence of the forearm may

64 preclude the use of SMG for classifying motion. Thus, the purpose of this exploratory study was

65 to quantify the motion classification accuracy achievable by an individual with transhumeral

66 limb loss using SMG. A secondary aim was to directly compare motion classification using

67 EMG and SMG in order to understand the relative merits of each modality. 


\section{Methods}

\section{Subject}

The subject underwent bilateral wrist disarticulation (right arm) and transhumeral (left

72 arm) amputations nine years prior to this data collection. The subject reported use of a pattern

73 recognition controlled prosthesis consisting of an externally-powered elbow, wrist and terminal

74 device on a daily basis for over two years. Before that, the subject had used a direct controlled

75 hybrid prosthesis (body-powered elbow, externally-powered wrist and terminal device) for six

76 years. Both devices were attached to the transhumeral residual limb via a suspension socket.

77 Although the subject had been exposed to SMG approximately one year prior to this data

78 collection, he had only used it with his right arm and was naïve to its use with the arm affected

79 by transhumeral amputation. The study protocol was approved by the George Mason University

80 Institutional Review Board and the subject provided written informed consent prior to 81 participating.

\section{Data acquisition with sonomyography}

All data were acquired from the subject's transhumeral residual limb. A Terason uSmart

$853200 \mathrm{~T}$ ultrasound system (Terason, Burlington, MA) was used for the studies. A low-profile,

86 high-frequency, linear 16HL7 ultrasound transducer was positioned on the subject's residual

87 limb using a stretchable fabric cuff. Ultrasound image sequences were acquired at a sampling

88 rate of $13.44+/-0.66 \mathrm{~Hz}$ and transferred to a PC in real-time using an Epiphan screen capture

89 card (Epiphan Systems, Palo Alto, CA), where they were processed in MATLAB (MathWorks,

90 Natick, MA) using custom algorithms. Note that the sampling rate was variable due to 
medRxiv preprint doi: https://doi.org/10.1101/2020.12.23.20248489; this version posted December 26, 2020. The copyright holder for this preprint (which was not certified by peer review) is the author/funder, who has granted medRxiv a license to display the preprint in perpetuity.

It is made available under a CC-BY-NC-ND 4.0 International license .

91 limitations imposed by the integration of the screen capture card with MATLAB. However, this

92 does not drastically impact our study as the classification procedure discussed herein does not

93 rely on temporal information.

94 The subject created a single dataset containing a set of 11 motions (index finger flexion,

95 middle finger flexion, ring finger flexion, little finger flexion, thumb abduction, power grasp, key

96 grasp, tripod, point, pinch, wrist pronation). In addition, a rest state was defined when it was

97 assumed the subject was not volitionally performing any of the motions and the residual

98 musculature was in a neutral position. Following a previously described protocol [32], the

99 subject performed each movement starting from a resting position and moving towards the

100 motion end-state within one second according to an auditory cue. He then held the end state for

101 one second, moved back to rest within one second, and remained at rest for another second.

102 Thus, there were four phases per motion performance: rest, transition from rest to motion end-

103 state, motion end-state, and transition from motion end-state to rest. Each motion performance

104 was repeated five times, resulting in 11 separate 20 -second sequences. A short break was

105 provided between the collection of each sequence when the subject switched to a new motion.

106

107 Data acquisition with electromyography

108 All data were acquired from the subject's transhumeral residual limb. Raw EMG signals

109 were gathered at a $1 \mathrm{kHz}$ sampling rate with eight bipolar anodized titanium electrodes (Infinite

110 Biomedical Technologies, Baltimore, MD) embedded within a custom transhumeral socket. The

111 electrodes were amplified and filtered with a $20-500 \mathrm{~Hz}$ digital bandpass and $60 \mathrm{~Hz}$ digital

112 notch filters. The subject created a single dataset containing the same set of 11 motions and 
medRxiv preprint doi: https://doi.org/10.1101/2020.12.23.20248489; this version posted December 26, 2020. The copyright holder for this preprint (which was not certified by peer review) is the author/funder, who has granted medRxiv a license to display the preprint in perpetuity.

It is made available under a CC-BY-NC-ND 4.0 International license .

113 following the same temporal sequence described previously. The only difference was that visual

114 cues, rather than auditory cues, were provided to prompt transitions between states.

115

116 Data analysis

The EMG and SMG sensing modalities produce very different data and were subjected to

118 different pre-processing steps. The EMG data were split into $100 \mathrm{~ms}$ windows at every $10 \mathrm{~ms}$

119 interval. Five features were extracted from each of the windows: mean absolute value, variance,

120 slope sign change count, waveform length, and number of zero crossings. The SMG data are

121 acquired as a stream of individual ultrasound image frames. These ultrasound frames have a very

122 large number of pixels and thus a very high dimensionality (1400x1000). To reduce the number

123 of features, we first downscaled the images to one-tenth the original size (140x100), and then

124 utilized principal component analysis to further reduce the dimensionality. We retained every

125 basis vector that explained greater than $0.01 \%$ of the variance in the data, leading to a total

126 explained variance of approximately 97\%. Once the data were processed, each datapoint (time

127 window for EMG, ultrasound image for SMG) was assigned a phase label based on the

128 metronome cues. Thus, the datapoints were labeled as rest during the first second of motion

129 performance, transition to the motion end-state during the next second, motion end-state during

130 the third second, and transition from the motion end-state during the fourth second. This pattern

131 of labelling was repeated for all five motion repetitions in the 20 -second sequence.

132 Although the preprocessing was different for the two sensing strategies, the classification

133 analysis for both the SMG and EMG datasets was performed using a linear discriminant analysis

134 classifier. The classifier was constrained to have equal prior probabilities for each of the 12

135 possible classes (11 motions and rest). Leave-one-out cross-validation was performed such that 
medRxiv preprint doi: https://doi.org/10.1101/2020.12.23.20248489; this version posted December 26, 2020. The copyright holder for this preprint (which was not certified by peer review) is the author/funder, who has granted medRxiv a license to display the preprint in perpetuity.

It is made available under a CC-BY-NC-ND 4.0 International license .

136 one of the 55 motion performances (11 motions $x 5$ trials) were selected as a test set while the

137 remaining 54 motion performances were used for training. This process was repeated for each of

138 the 55 motion performances and a list of predictions for all data was compiled. Based on the

139 phase labels, we then created confusion matrices and calculated the percent of correct predictions

140 for each of the 4 phases, as well as the overall dataset.

141 For this work, we considered two different methods for training the classifier. Since we

142 are primarily interested in evaluating the extent to which we can enable basic motion

143 classification in individuals with transhumeral limb loss, we first trained the classifier using only

144 data labelled as belonging to the rest and motion end-state phases where the user's performance

145 is most stable. However, we are also interested in understanding the extent to which we can

146 facilitate an intuitive control paradigm that mimics the natural control employed with intact

147 limbs. Our previous work has shown that SMG may eventually enable proportional positional

148 control of prostheses [32] that allows users to rely on their innate proprioceptive sensing [34] to

149 drive their device in a way that is directly congruent with their level of muscle contraction.

150 Therefore, evaluating whether the classifier can accurately detect partially completed grasps is a

151 necessary step towards demonstrating the feasibility of achieving proportional positional control.

152 Being able to successfully detect partially completed grasps would also permit earlier

153 classification of hand gestures than if the user was required to fully complete the grasp, thus

154 increasing the responsiveness of the prosthetic device. As such, we also trained the classifier

155 using data from the transition phases when grasps are partially completed, in addition to the rest

156 and motion end-state phases.

157 Although the subject received cues to transition between each phase in the data 158 acquisition sequence, it is likely that there were some delays due to reaction time following each 
medRxiv preprint doi: https://doi.org/10.1101/2020.12.23.20248489; this version posted December 26, 2020. The copyright holder for this preprint (which was not certified by peer review) is the author/funder, who has granted medRxiv a license to display the preprint in perpetuity.

It is made available under a CC-BY-NC-ND 4.0 International license .

159 cue. For example, they may have continued to remain at rest for a brief time even after receiving

160 the cue to begin transitioning to the motion end-state. Thus, it is difficult to know whether a rest

161 prediction during a transition phase is truly incorrect (i.e., misclassification of a motion state as

162 rest) or correct (i.e., the subject was at rest and the classifier predicted rest). Because of this

163 ambiguity, the classification performance is reported under both assumptions. The same

164 classifier predictions were used to compute the classification accuracy in both scenarios. The

165 only difference was that prediction of any motion during a transition phase as rest was counted

166 as a failure when rest was considered incorrect, but was counted as a success when rest was

167 considered correct. Together, the two scenarios provide both a conservative (rest considered

168 incorrect) and best-case (rest considered correct) estimate of classification accuracy.

170 Results

\section{Training with steady state phases only}

172 Visual inspection of the predicted classifications throughout the entire data acquisition

173 period indicates that the classifier usually predicted motion classes correctly for both modalities

174 (Fig 1). However, the overall classification accuracy for all 11 motion classes plus rest was

175 higher for SMG than EMG (Fig 2). This was true regardless of whether rest predictions during

176 transitions were considered correct (EMG: 80.79\%, SMG: 97.90\%) or incorrect (EMG: 61.52\%,

177 SMG: 72.93\%). Similarly, classification accuracy during the motion end-state phases (Fig 3) was

178 higher for SMG (EMG: 75.08\%, SMG: 94.04\%). Classification accuracy during the rest phases

179 was roughly equivalent between the two modalities (EMG: 96.25\%, SMG: 98.34\%). 
medRxiv preprint doi: https://doi.org/10.1101/2020.12.23.20248489; this version posted December 26, 2020. The copyright holder for this preprint (which was not certified by peer review) is the author/funder, who has granted medRxiv a license to display the preprint in perpetuity.

It is made available under a CC-BY-NC-ND 4.0 International license .

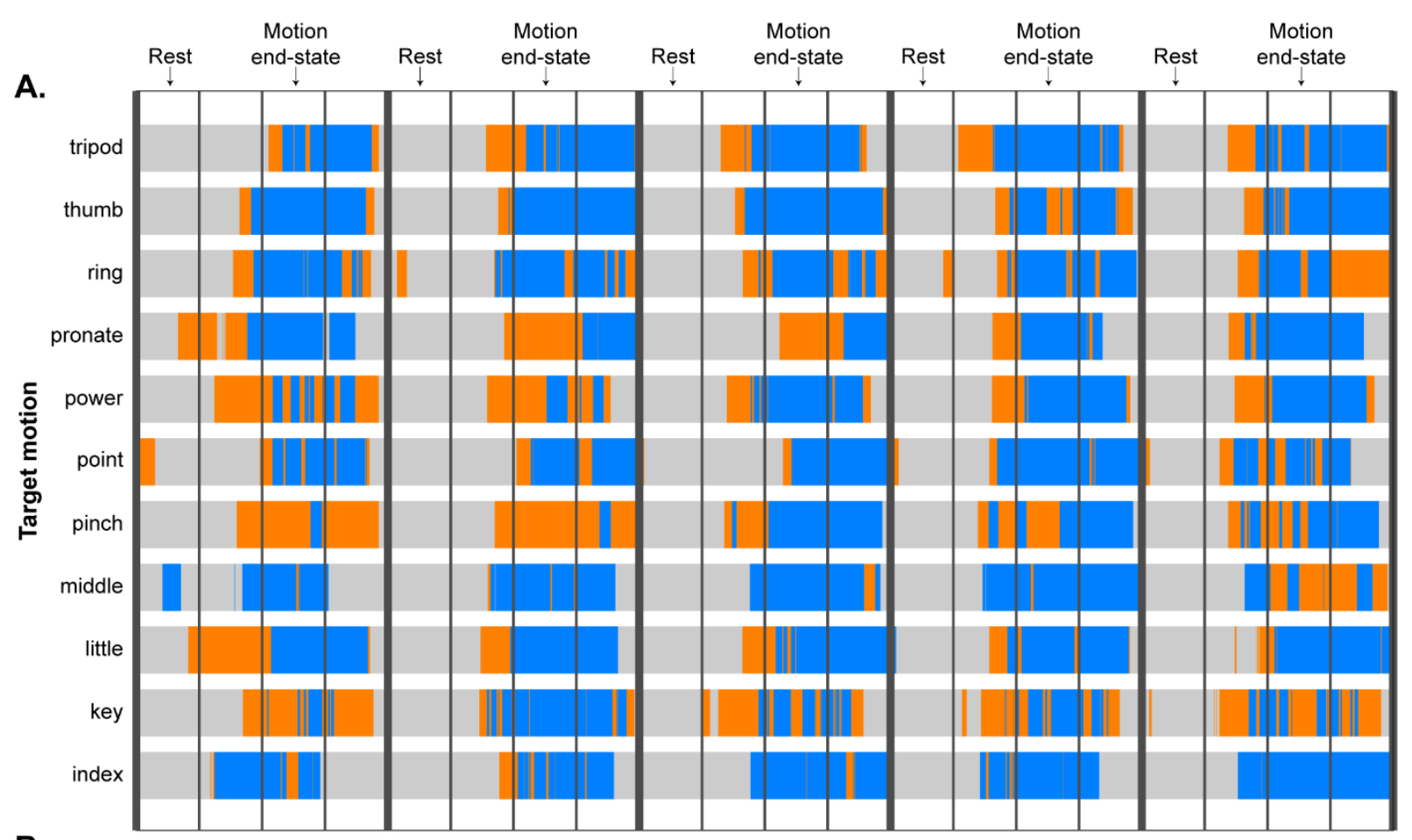

B.

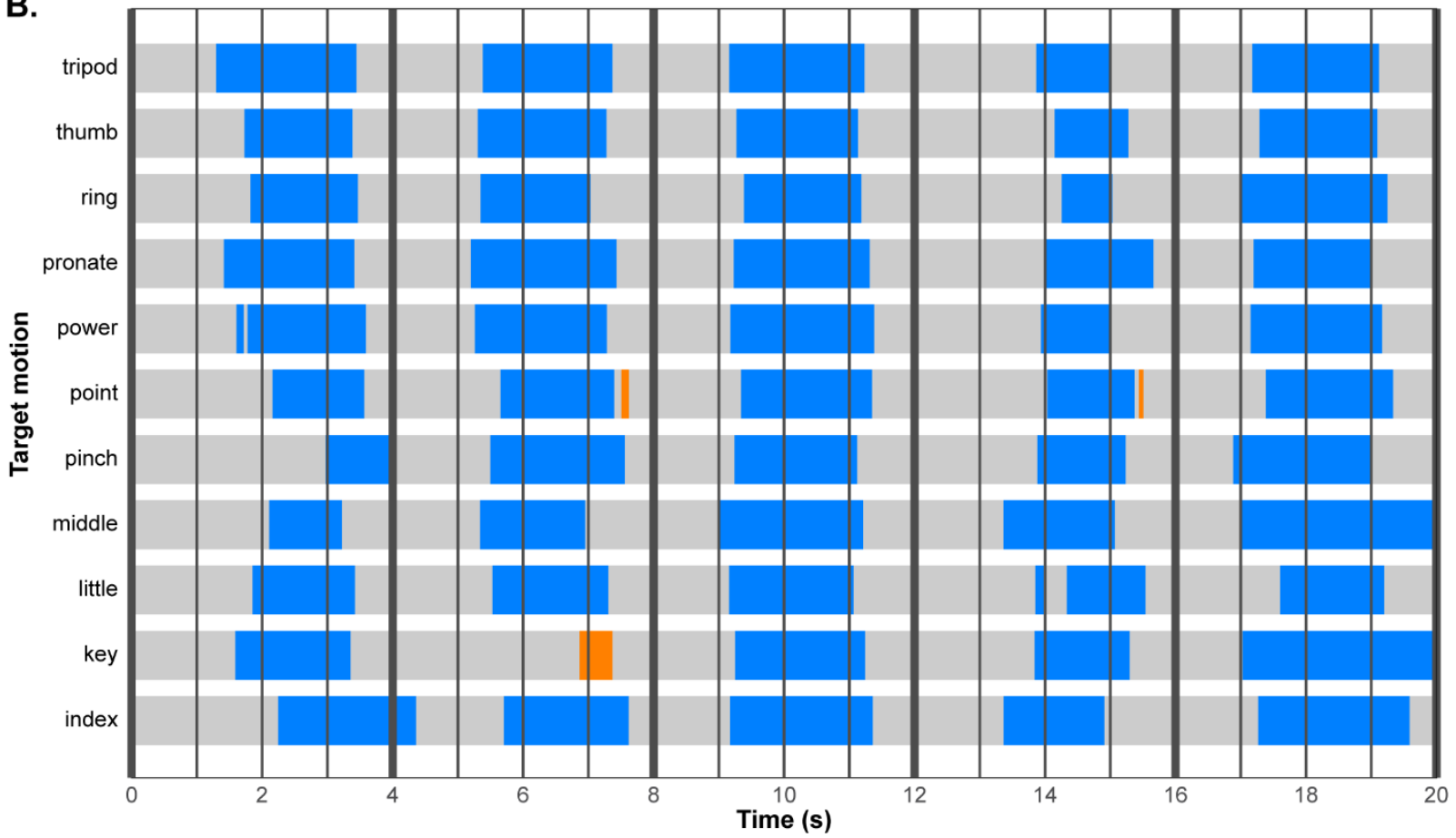

Fig 1. Motion class predictions over time. The temporal progression of motion class predictions is shown for all EMG time windows (A) and SMG image frames (B). Vertical lines represent metronome cues prompting a transition between phases. Each rest and motion end-state phase was followed by a one-second transition period during which the subject transitioned to the next phase. Rest predictions are indicated in grey, target motion predictions are indicated in 186 blue, and predictions of any of the other 10 motions are indicated in orange. 
medRxiv preprint doi: https://doi.org/10.1101/2020.12.23.20248489; this version posted December 26, 2020. The copyright holder for this preprint (which was not certified by peer review) is the author/funder, who has granted medRxiv a license to display the preprint in perpetuity.

It is made available under a CC-BY-NC-ND 4.0 International license .

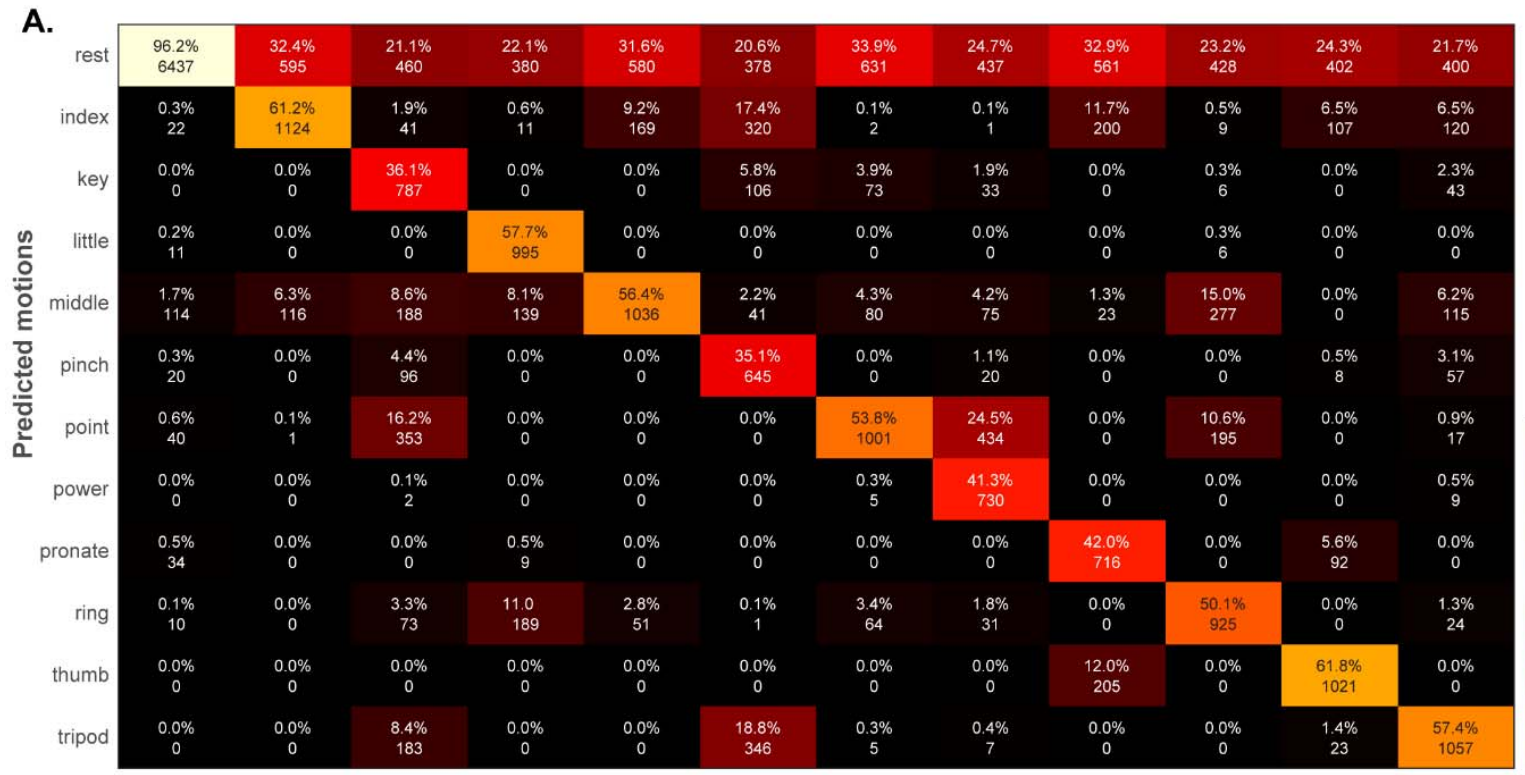

B.

188

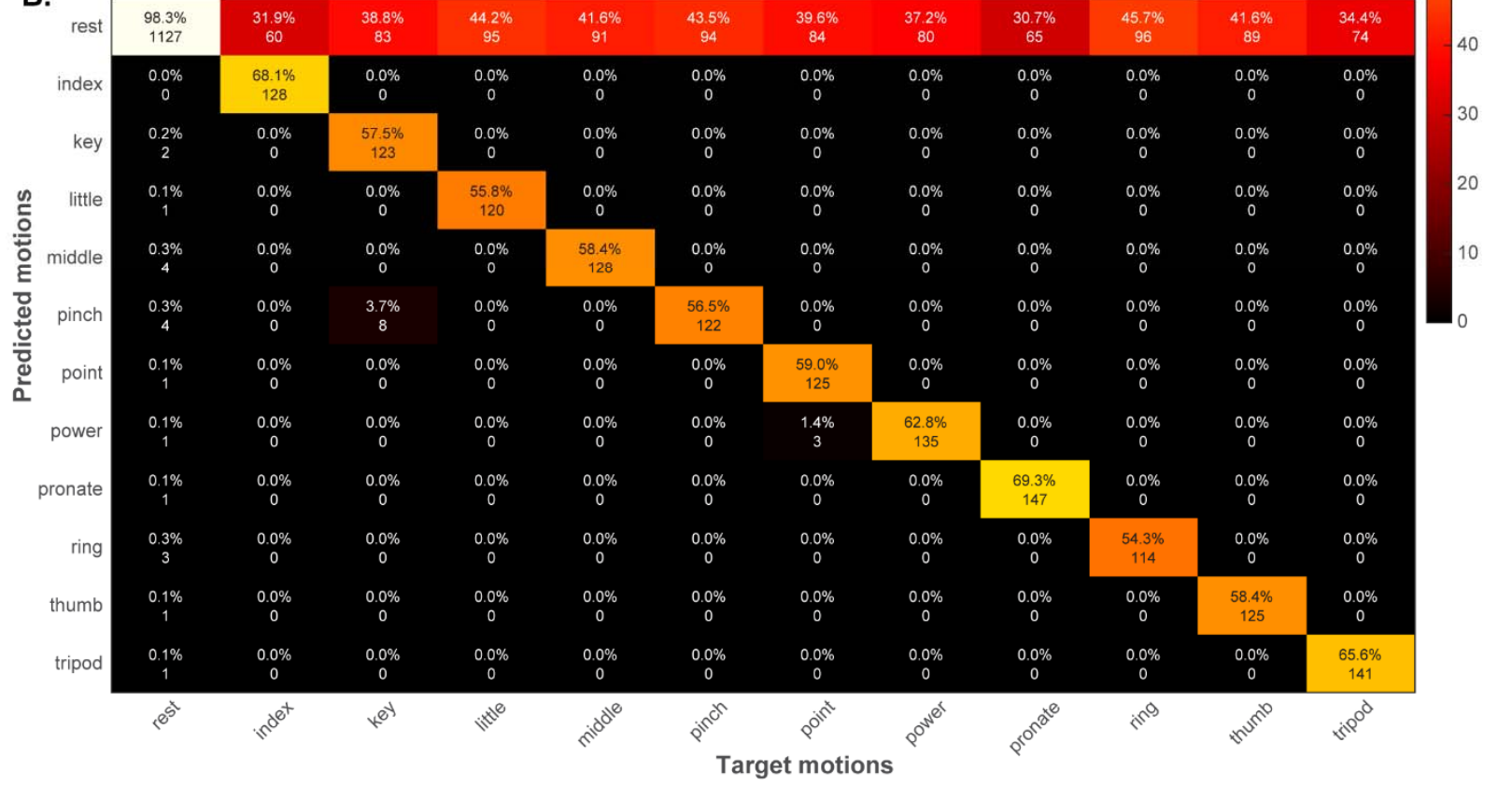

189 Fig 2. Overall confusion matrices. Prediction accuracies are shown for EMG (A) and SMG (B). 190 The integer values in each cell represent the total number of EMG time windows or SMG image 191 frames that were classified.

192 
medRxiv preprint doi: https://doi.org/10.1101/2020.12.23.20248489; this version posted December 26, 2020. The copyright holder for this preprint (which was not certified by peer review) is the author/funder, who has granted medRxiv a license to display the preprint in perpetuity.

It is made available under a CC-BY-NC-ND 4.0 International license .

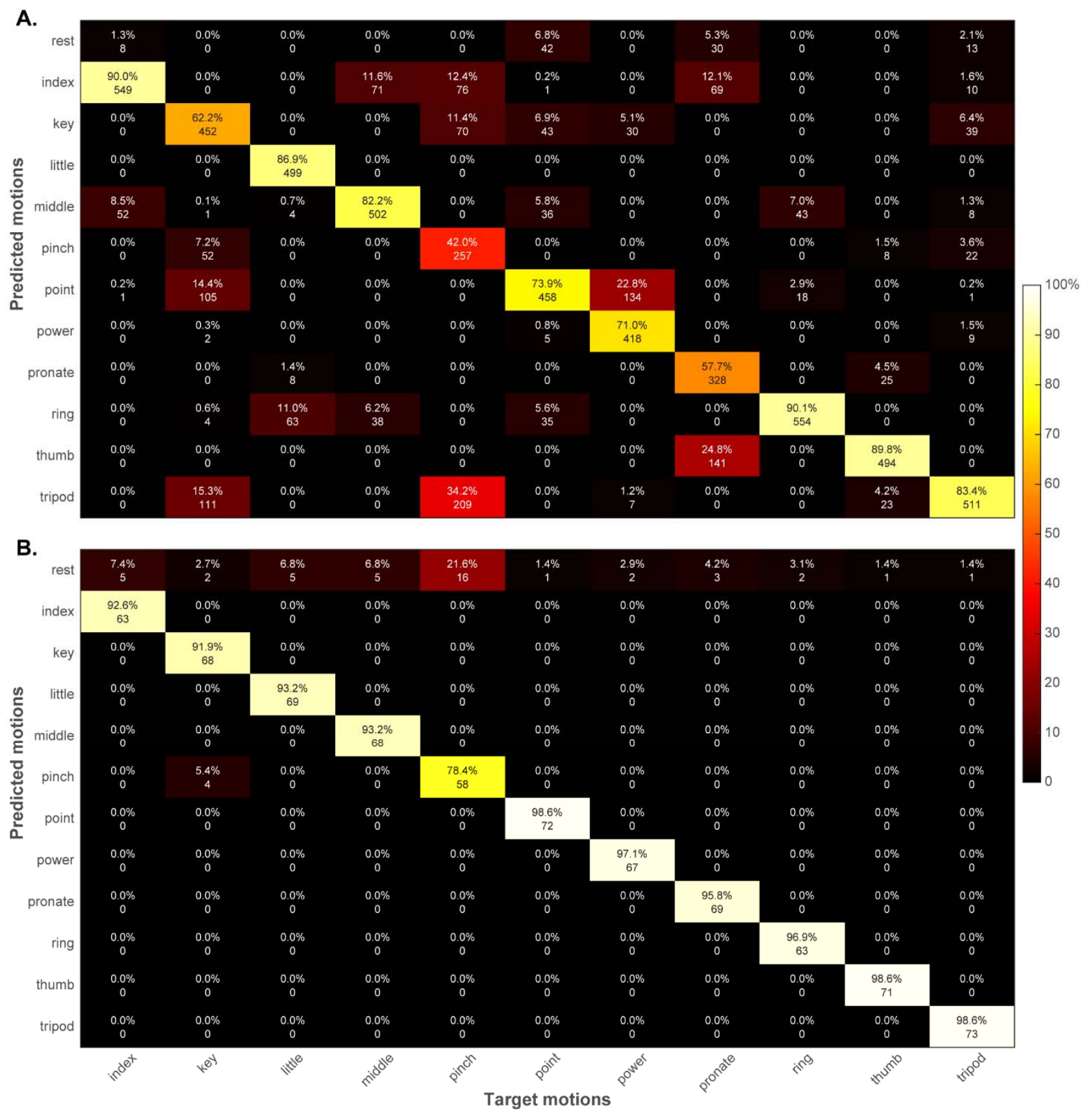

193

Fig 3. Confusion matrices for the motion end-state phases. Prediction accuracies are shown for EMG (A) and SMG (B). The integer values in each cell represent the total number of EMG time windows or SMG image frames that were classified.

During the transition periods from rest to a motion end-state, classification accuracy was higher for SMG (Fig 4) both when rest predictions were considered correct (EMG: 70.64\%, SMG: 100.00\%) and incorrect (EMG: 15.48\%, SMG: 67.37\%). During the transition periods from a motion end-state to rest (Fig 5), classification accuracy was higher for SMG only when 
medRxiv preprint doi: https://doi.org/10.1101/2020.12.23.20248489; this version posted December 26, 2020. The copyright holder for this preprint (which was not certified by peer review) is the author/funder, who has granted medRxiv a license to display the preprint in perpetuity.

It is made available under a CC-BY-NC-ND 4.0 International license .

203 considered incorrect, classification accuracy was higher for EMG (EMG: 59.31\%, SMG:

204 18.93\%). A summary of the classification accuracies for all phases is provided in Table 1.

205

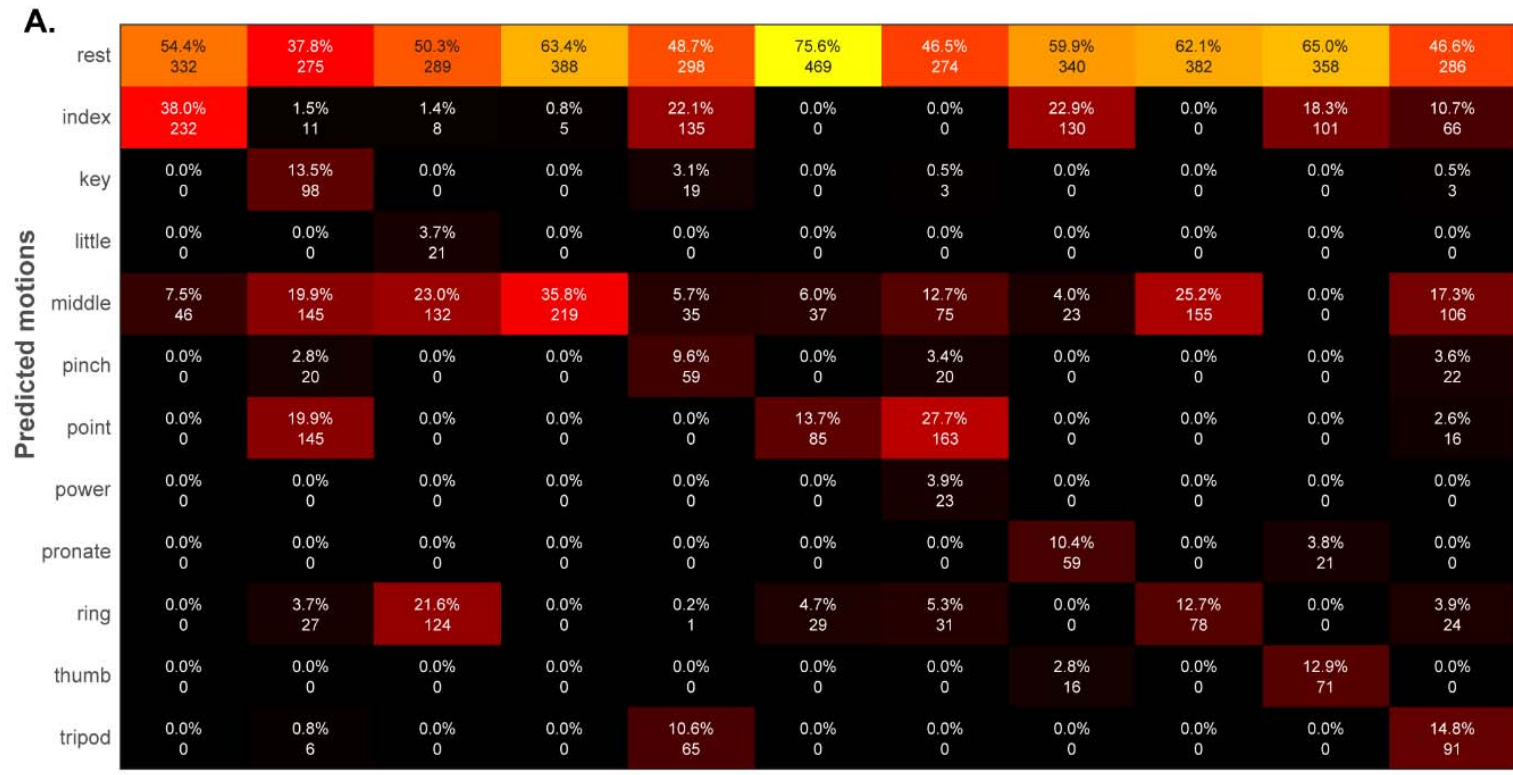

B.

Fig 4. Confusion matrices for the transitions from rest to motion. Prediction accuracies are 
medRxiv preprint doi: https://doi.org/10.1101/2020.12.23.20248489; this version posted December 26, 2020. The copyright holder for this preprint (which was not certified by peer review) is the author/funder, who has granted medRxiv a license to display the preprint in perpetuity.

It is made available under a CC-BY-NC-ND 4.0 International license .

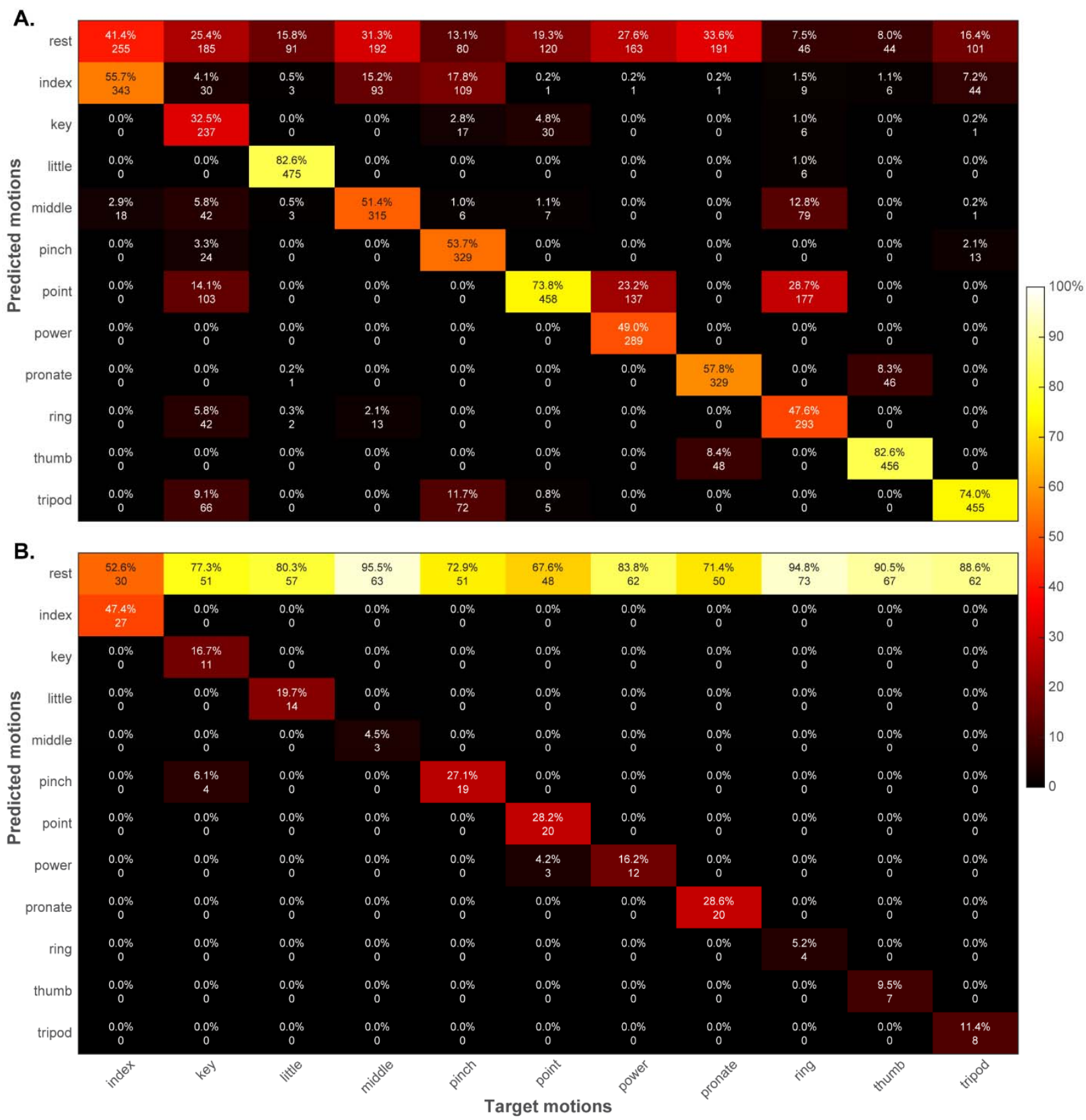

Fig 5. Confusion matrices for the transitions from motion to rest. Prediction accuracies are 213 shown for EMG (A) and SMG (B). The integer values in each cell represent the total number of 214 EMG time windows or SMG image frames that were classified. 
medRxiv preprint doi: https://doi.org/10.1101/2020.12.23.20248489; this version posted December 26, 2020. The copyright holder for this preprint (which was not certified by peer review) is the author/funder, who has granted medRxiv a license to display the preprint in perpetuity.

It is made available under a CC-BY-NC-ND 4.0 International license .

219 Table 1. Classification accuracies when partially completed grasps were excluded from 220 training.

\begin{tabular}{ccc}
\hline Data acquisition phase & EMG & SMG \\
\hline Rest & $96.25 \%$ & $98.34 \%$ \\
Motion end-state & $75.08 \%$ & $94.04 \%$ \\
\hline & Rest predictions & during transitions considered correct \\
Transition from rest to motion end-state & $70.64 \%$ & $100.00 \%$ \\
Transition from motion end-state to rest & $81.16 \%$ & $99.09 \%$ \\
All phases & $80.79 \%$ & $97.90 \%$ \\
\hline & Rest predictions during transitions considered incorrect \\
Transition from rest to motion end-state & $15.48 \%$ & $67.27 \%$ \\
Transition from motion end-state to rest & $59.31 \%$ & $18.93 \%$ \\
All phases & $61.52 \%$ & $72.93 \%$ \\
\hline
\end{tabular}

221

222 Training with steady state and transition phases

223 When partially completed grasps were included in the training, the classifier usually 224 predicted motion classes correctly (Fig 6) but with higher overall accuracy for SMG than EMG

225 (Fig 7). The accuracy was higher for SMG both when rest predictions during transitions were 226 considered correct (EMG: 76.44\%, SMG: 87.26\%) and incorrect (EMG: 62.38\%, SMG: 227 79.63\%). Classification accuracy was also higher for SMG during the motion end-state phases 228 (Fig 8, EMG: 77.53\%, SMG: 97.34\%) but was higher for EMG during the rest phases (EMG: $22978.29 \%$, SMG: 63.44\%). 
medRxiv preprint doi: https://doi.org/10.1101/2020.12.23.20248489; this version posted December 26, 2020. The copyright holder for this preprint (which was not certified by peer review) is the author/funder, who has granted medRxiv a license to display the preprint in perpetuity.

It is made available under a CC-BY-NC-ND 4.0 International license .

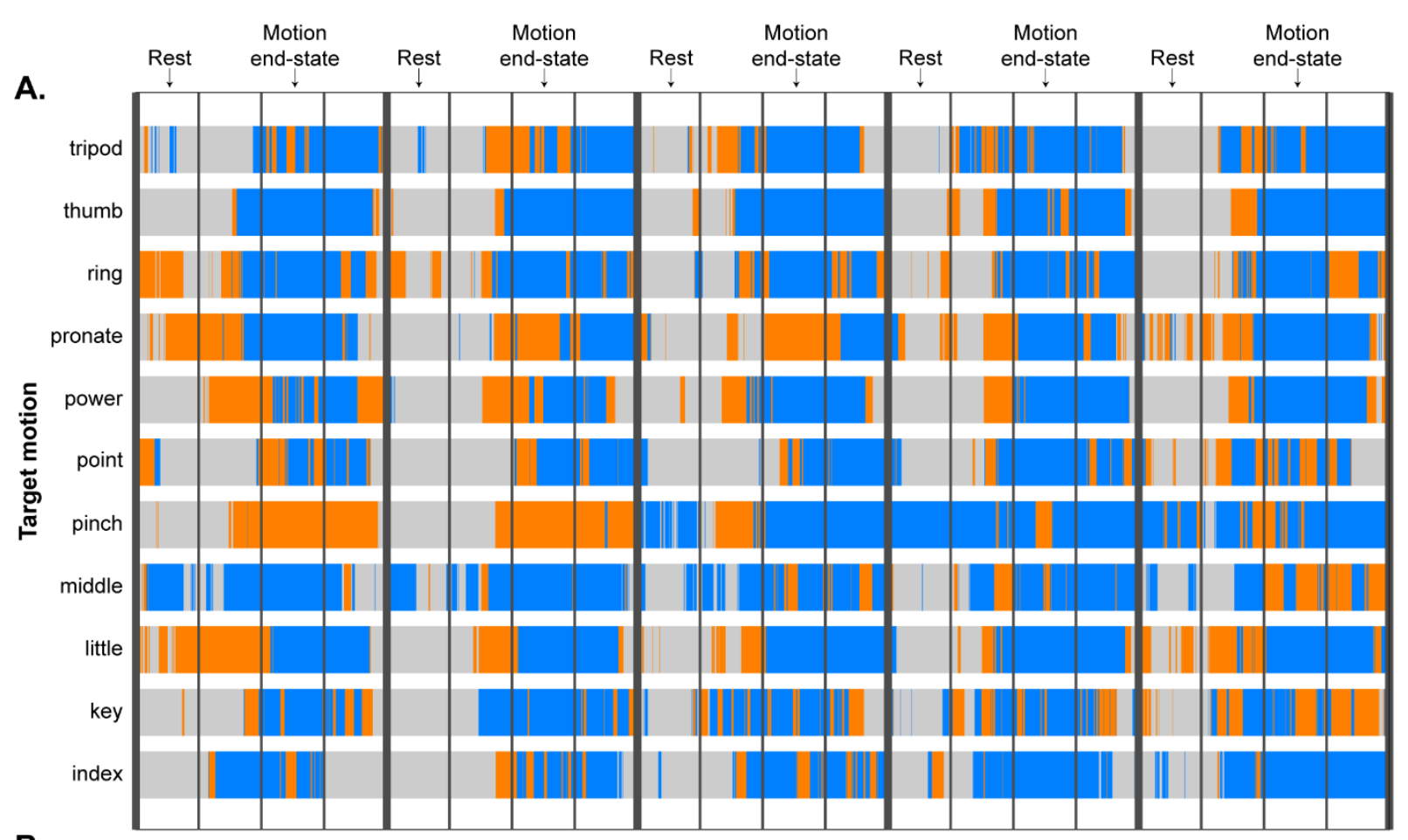

B.

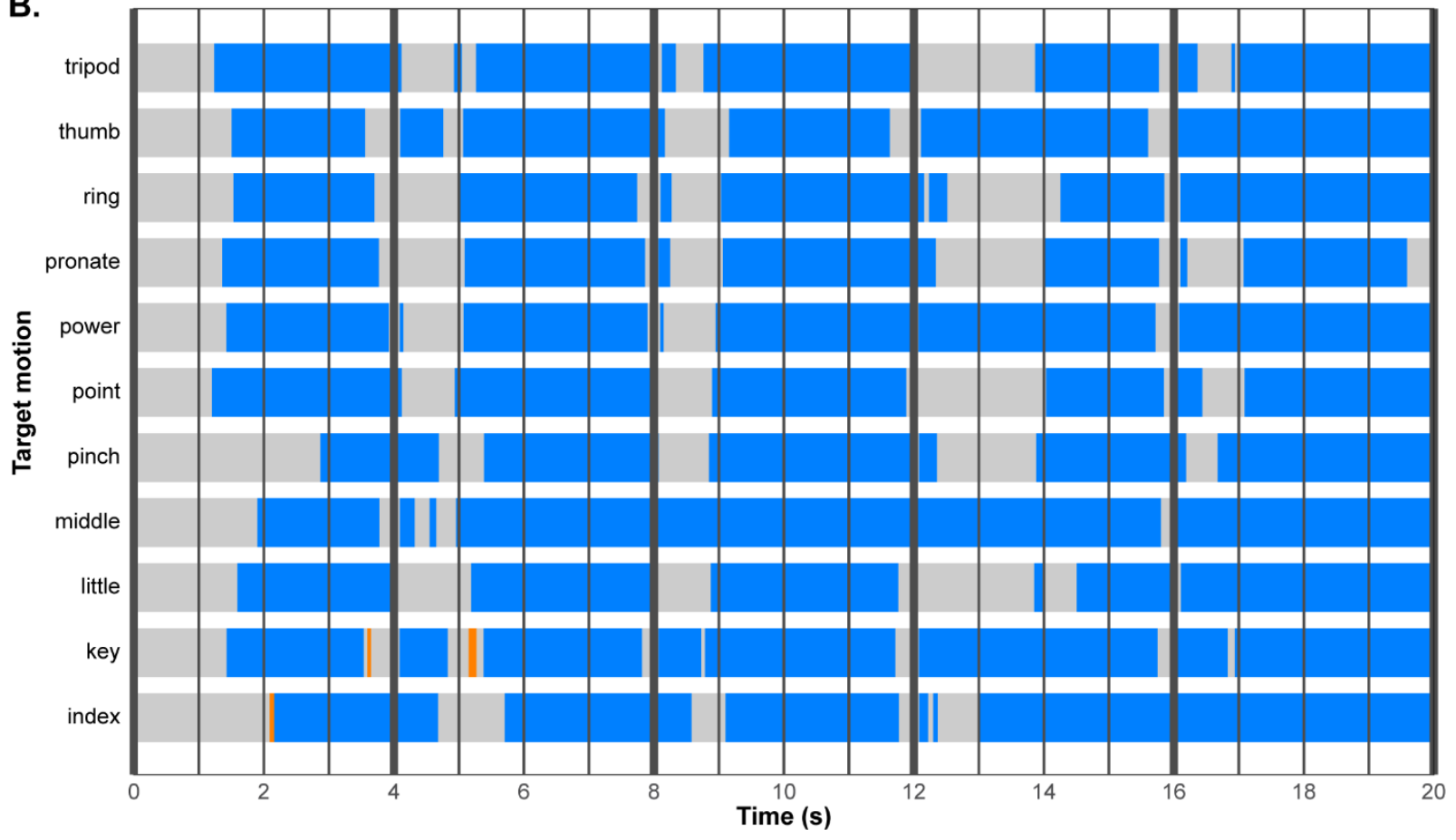

Fig 6. Motion class predictions over time. The temporal progression of motion class predictions is shown for all EMG time windows (A) and SMG image frames (B). Vertical lines represent metronome cues prompting a transition between phases. Each rest and motion end-state phase was followed by a one-second transition period during which the subject transitioned to the next phase. Rest predictions are indicated in grey, target motion predictions are indicated in blue, and predictions of any of the other 10 motions are indicated in orange. 
medRxiv preprint doi: https://doi.org/10.1101/2020.12.23.20248489; this version posted December 26, 2020. The copyright holder for this preprint (which was not certified by peer review) is the author/funder, who has granted medRxiv a license to display the preprint in perpetuity.

It is made available under a CC-BY-NC-ND 4.0 International license .

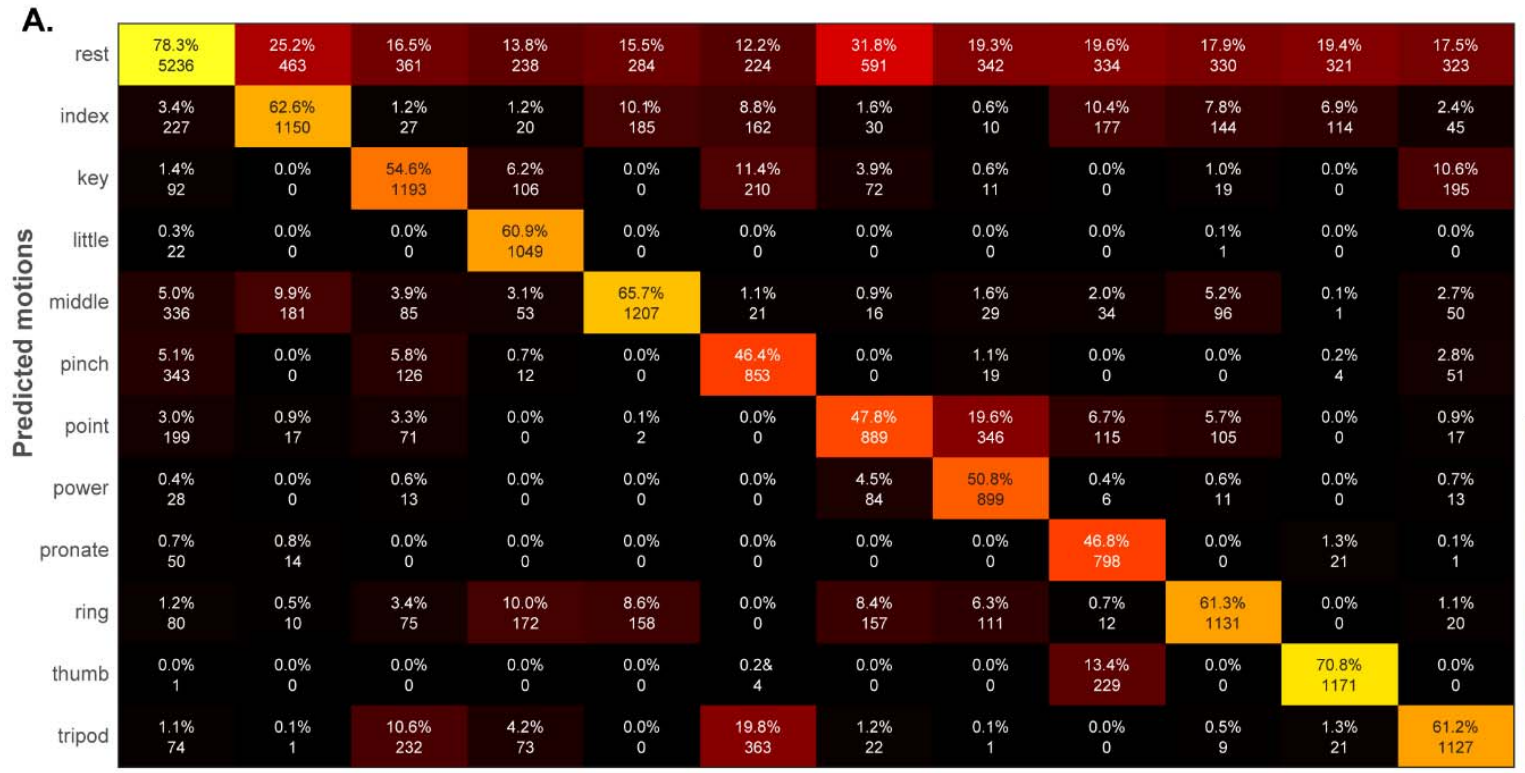

B.

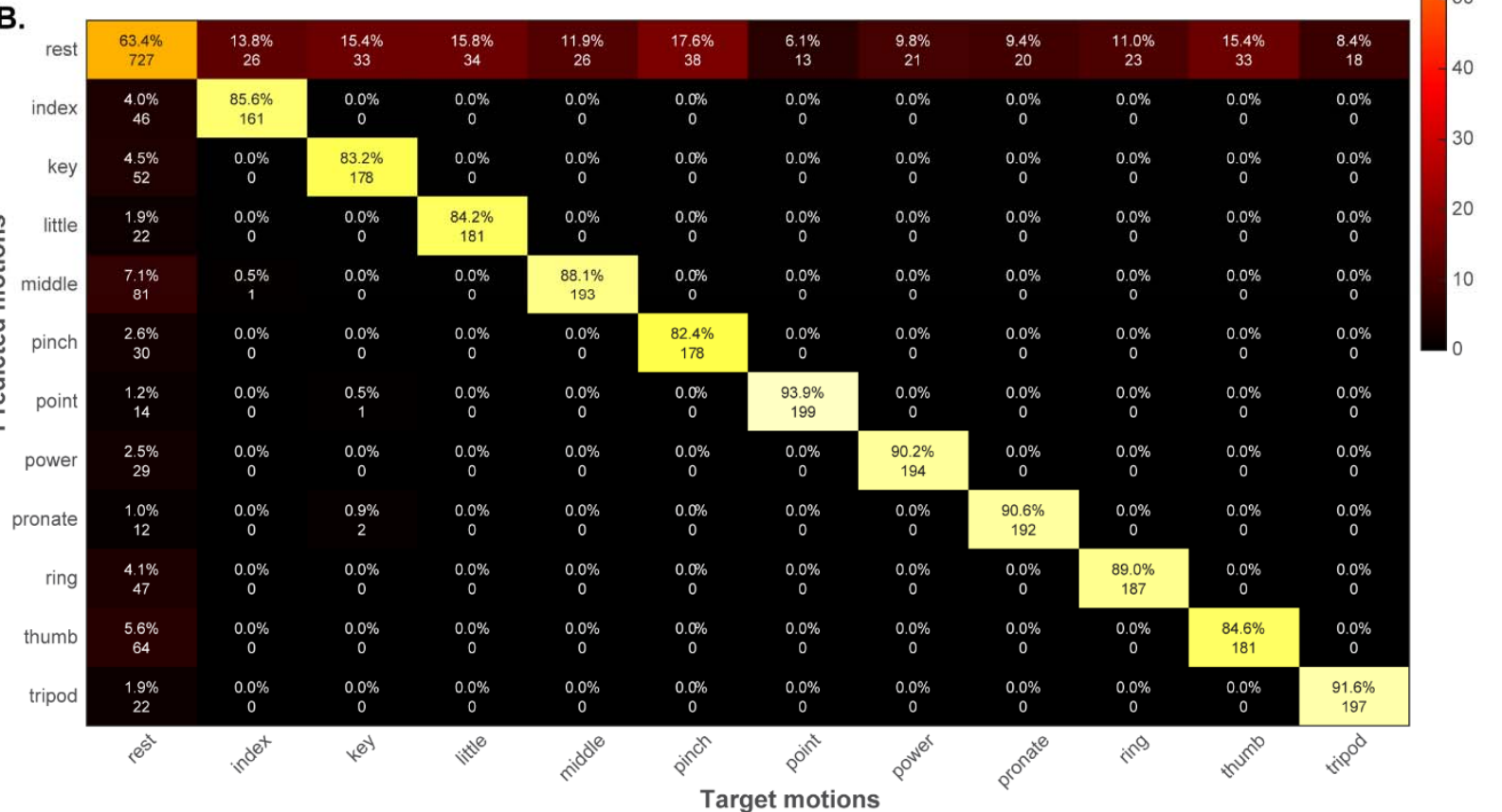

238

239

240

241

242
Fig 7. Overall confusion matrices. Prediction accuracies are shown for EMG (A) and SMG (B). The integer values in each cell represent the total number of EMG time windows or SMG image frames that were classified. 
medRxiv preprint doi: https://doi.org/10.1101/2020.12.23.20248489; this version posted December 26, 2020. The copyright holder for this preprint (which was not certified by peer review) is the author/funder, who has granted medRxiv a license to display the preprint in perpetuity.

It is made available under a CC-BY-NC-ND 4.0 International license .

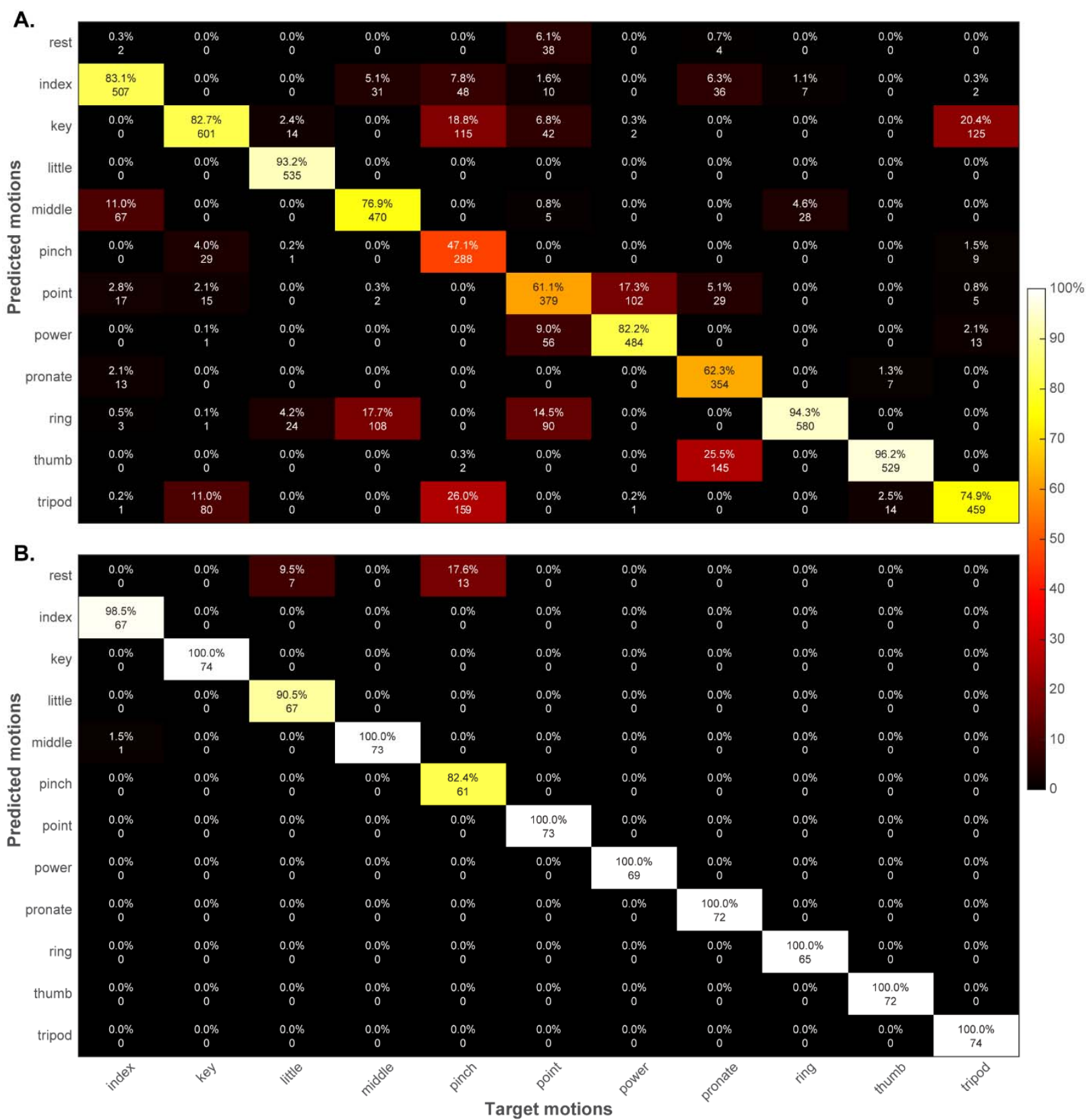

244 Fig 8. Confusion matrices for the motion end-state phases. Prediction accuracies are shown 245 for EMG (A) and SMG (B). The integer values in each cell represent the total number of EMG 246 time windows or SMG image frames that were classified.

249 higher for SMG if rest predictions were considered correct (EMG: 69.49\%, SMG: 99.74\%) or 250 incorrect (EMG: 27.50\%, SMG: 85.05\%). Classification accuracy was also higher for SMG 
medRxiv preprint doi: https://doi.org/10.1101/2020.12.23.20248489; this version posted December 26, 2020. The copyright holder for this preprint (which was not certified by peer review) is the author/funder, who has granted medRxiv a license to display the preprint in perpetuity.

It is made available under a CC-BY-NC-ND 4.0 International license .

251 during transitions from a motion end-state to rest (Fig 10). This was true regardless of whether

252 rest predictions were considered correct (EMG: 80.46\%, SMG: 99.87\%) or incorrect (EMG:

$25366.19 \%$, SMG: 80.16\%). A summary of the classification accuracies for all phases is provided in

254 Table 2.

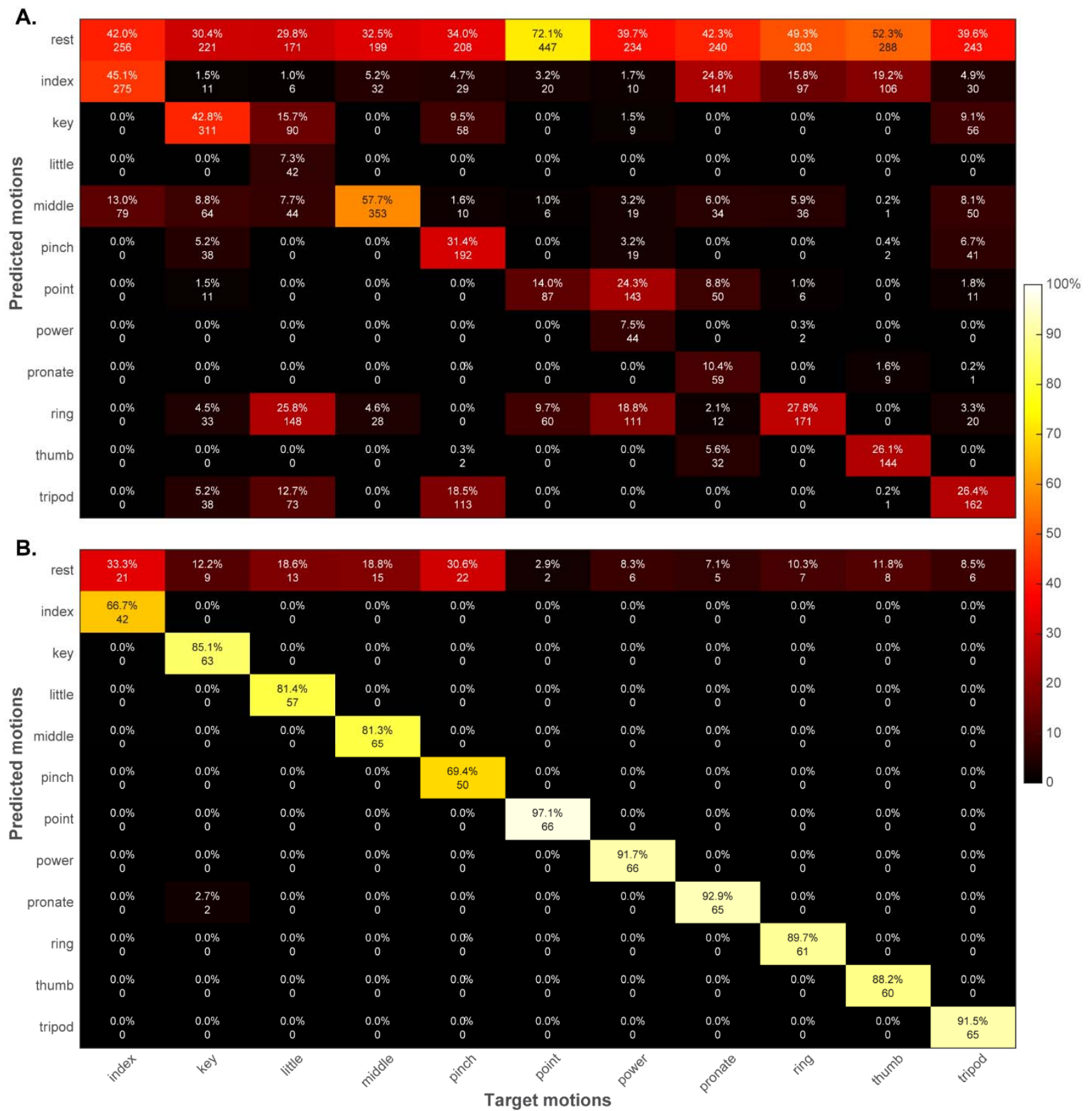

Target motions

256 Fig 9. Confusion matrices for the transitions from rest to motion. Prediction accuracies are 257 shown for EMG (A) and SMG (B). The integer values in each cell represent the total number of 258 EMG time windows or SMG image frames that were classified. 
medRxiv preprint doi: https://doi.org/10.1101/2020.12.23.20248489; this version posted December 26, 2020. The copyright holder for this preprint (which was not certified by peer review) is the author/funder, who has granted medRxiv a license to display the preprint in perpetuity.

It is made available under a CC-BY-NC-ND 4.0 International license .

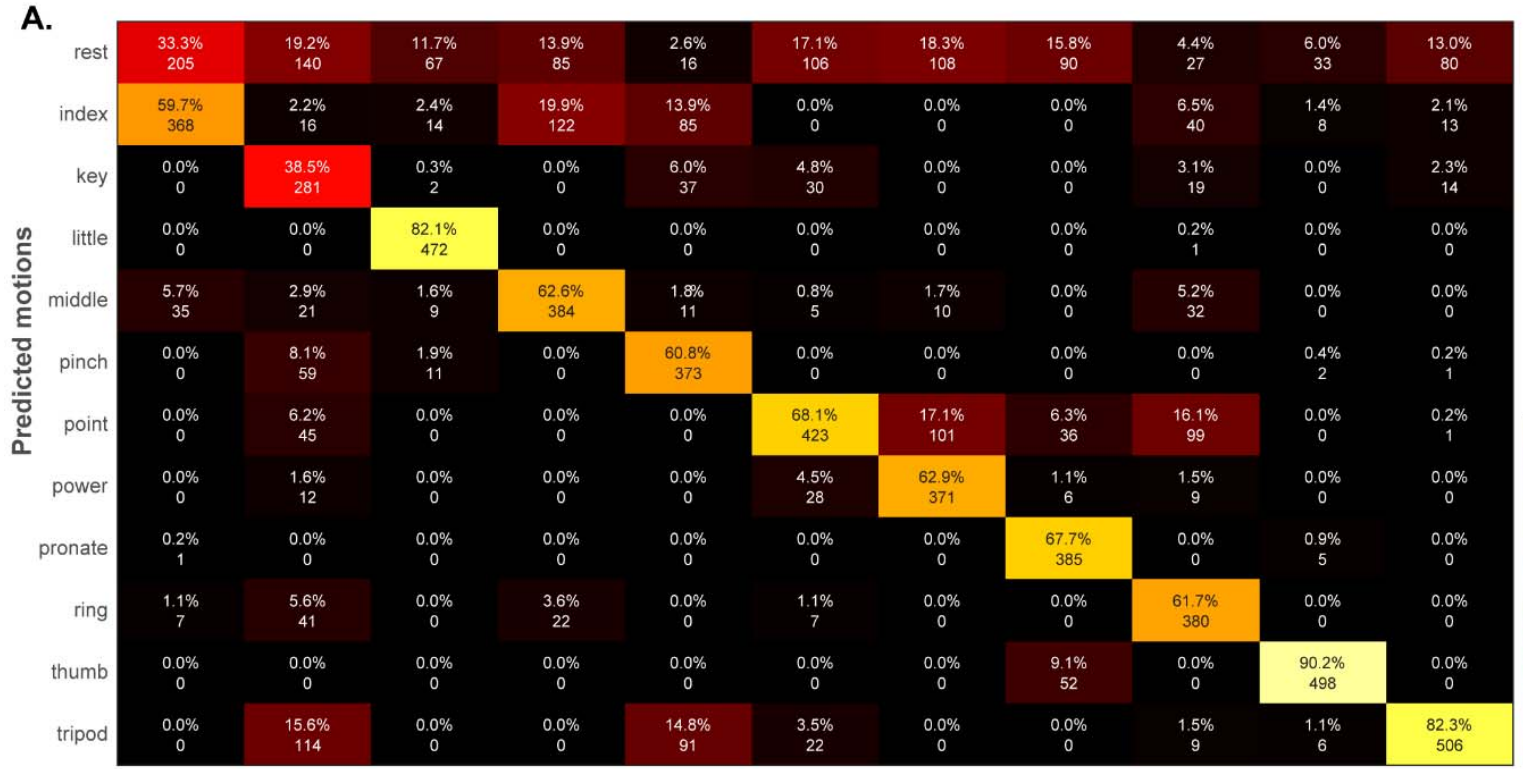

B.

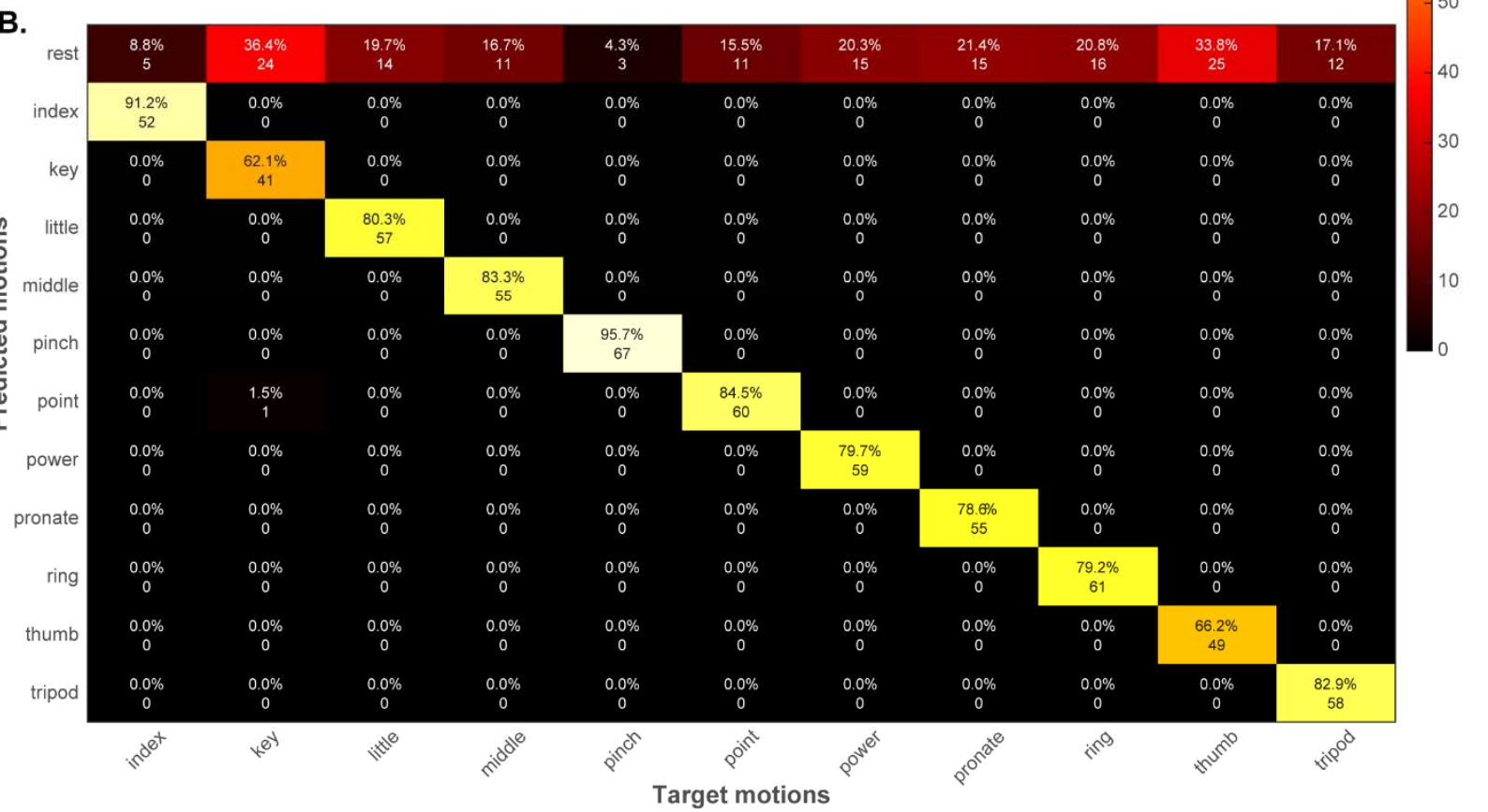

260

261

262

263

264

265 
medRxiv preprint doi: https://doi.org/10.1101/2020.12.23.20248489; this version posted December 26, 2020. The copyright holder for this preprint (which was not certified by peer review) is the author/funder, who has granted medRxiv a license to display the preprint in perpetuity.

It is made available under a CC-BY-NC-ND 4.0 International license .

Table 2. Classification accuracies when partially completed grasps were included in 269 training.

\begin{tabular}{ccc}
\hline Data acquisition phase & EMG & SMG \\
\hline Rest & $78.29 \%$ & $63.44 \%$ \\
Motion end-state & $77.53 \%$ & $97.34 \%$ \\
\hline & Rest predictions & during transitions considered correct \\
Transition from rest to motion end-state & $69.49 \%$ & $99.74 \%$ \\
Transition from motion end-state to rest & $80.46 \%$ & $99.87 \%$ \\
All phases & $76.44 \%$ & $87.26 \%$ \\
\hline & Rest predictions during transitions considered incorrect \\
Transition from rest to motion end-state & $27.50 \%$ & $85.05 \%$ \\
Transition from motion end-state to rest & $66.19 \%$ & $80.16 \%$ \\
All phases & $62.38 \%$ & $79.63 \%$ \\
\hline
\end{tabular}

270

271 Discussion

This work provides the first documentation of successful motion classification in an

273 individual with transhumeral limb loss using SMG. Notably, the subject was able to accomplish

274 both individual finger movements and complex grasps. Recognizing finger motions with EMG is

275 challenging since the muscles responsible for finger movement are largely contained within the

276 intermediate and deep compartments of the forearm, meaning that the electrical activity is

277 attenuated by the overlying tissue [20]. SMG appears to be more well-suited for classifying

278 individual digit motion given its ability to detect deformation in both superficial and deep

279 muscles [27,35,36]. Nonetheless, classifying individual finger motion could be problematic in

280 individuals with transhumeral limb loss given the complete absence of forearm musculature.

281 Our subject's ability to successfully classify both individual finger movements and

282 complex grasps using SMG may be a consequence of procedures used during his amputation

283 surgery. The surgeons removed necrotic tissue and deinnervated some muscles in the residual

284 limb. We hypothesize that these muscles may have spontaneously reinnervated during recovery,

285 although this hypothesis could not be directly tested and only indirect inference is possible. The

286 surgery was not performed with the expectation that reinnervation would occur. Therefore, if our 
medRxiv preprint doi: https://doi.org/10.1101/2020.12.23.20248489; this version posted December 26, 2020. The copyright holder for this preprint (which was not certified by peer review) is the author/funder, who has granted medRxiv a license to display the preprint in perpetuity.

It is made available under a CC-BY-NC-ND 4.0 International license .

287 hypothesis is true, this case could be evidence of spontaneously-occurring muscle reinnervation

288 [37]. As a planned surgical procedure, targeted muscle reinnervation has shown great promise

289 for restoring wrist, hand, and finger control to patients with proximal limb loss (e.g., [13]).

290 During surgery, severed nerves that previously controlled arm and hand function are transferred

291 to muscles in the residual limb that no longer serve a biomechanical purpose. Thus, an attempt to

292 move the missing arm or hand will result in contraction of the reinnervated muscles. The

293 individual can then generate a wider variety of distinct muscle contractions than if the muscles

294 had not been transferred. Since our subject shows similar diversity in his residual limb

295 movement when performing the 11 gestures used in this study, we hypothesize that spontaneous

296 reinnervation may have occurred.

297 If spontaneous reinnervation was indeed responsible for our subject's robust

298 classification performance, it is possible that other individuals who have undergone more

299 traditional transhumeral amputations would be unable to achieve similar levels of success. A

300 larger group of individuals with transhumeral limb loss must be studied to determine whether

301 SMG can be a viable control strategy for this population. It would also be interesting to consider

302 the use of SMG as an alternative to EMG pattern recognition in those who have formally

303 undergone targeted muscle reinnervation.

304 A secondary aim of this work was to directly compare motion classification using EMG

305 and SMG in order to understand the relative merits of each modality. In general, the motion

306 classification accuracy was higher for SMG than EMG. This was true regardless of whether

307 partially completed grasps were excluded or included during training. There were only two

308 exceptions. First, the classification accuracy was higher for EMG during transitions from a

309 motion end-state to rest if rest predictions were assumed to be incorrect and training was 
medRxiv preprint doi: https://doi.org/10.1101/2020.12.23.20248489; this version posted December 26, 2020. The copyright holder for this preprint (which was not certified by peer review) is the author/funder, who has granted medRxiv a license to display the preprint in perpetuity.

It is made available under a CC-BY-NC-ND 4.0 International license .

310 performed without partially completed grasps. Second, the classification accuracy was higher for

311 EMG during rest if training was performed with partially completed grasps.

312 Within each modality, the effect of including partially completed grasps was inconsistent

313 between phases. During motion end-state phases, classification accuracy was similar within each

314 modality whether or not partially completed grasps were included during training. However,

315 including partially completed grasps during training reduced classification accuracy for rest

316 phases, especially for SMG. Classification accuracies during transitions were similar within each

317 modality regardless of whether partially completed grasps were included during training, but

318 only if rest was considered a correct prediction. If rest was considered incorrect, including

319 partially completed grasps increased classification accuracy within each modality.

320 Taken together, these findings indicate that including partially completed grasps during

321 training does not necessarily improve classification accuracy and also comes at the expense of

322 deterioration in rest prediction accuracy. This reduction in accuracy might occur because low-

323 level muscle activity can be classified as movement if partially completed grasps are included in

324 training. If only rest and motion end-states were included in training, then low-level muscle

325 activity would more likely be classified as rest until it became pronounced enough to resemble a

326 motion end-state. This issue could be exacerbated by the high spatial specificity of SMG, which

327 enables the detection of minute muscular deformations. Additionally, muscular rest states are not

328 constant since the muscles retain some residual deformation even after a contraction is

329 completed. However, inclusion of partial grasps during training did not reduce prediction

330 accuracy during transitions.

331 Although the reduction in rest prediction accuracy may appear undesirable, we do not

332 believe it will be overly problematic. We intend to use SMG to implement proportional 
medRxiv preprint doi: https://doi.org/10.1101/2020.12.23.20248489; this version posted December 26, 2020. The copyright holder for this preprint (which was not certified by peer review) is the author/funder, who has granted medRxiv a license to display the preprint in perpetuity.

It is made available under a CC-BY-NC-ND 4.0 International license .

333 positional control strategies [32], in which the finger positions on a prosthetic hand are mapped

334 proportionally to the amount of muscle deformation in a user's residual limb. In this paradigm,

335 misclassifying some rest states as motion may be tolerable since each motion prediction would

336 be accompanied by a predicted motion completion level. Thus, misclassification of rest as a

337 partially completed motion could be considered a more reasonable trade-off than misclassifying

338 rest as a fully completed motion, which would occur if proportional control is not enabled.

339 However, if this trade-off proves to be intolerable from a user's perspective, other approaches

340 may be considered to improve the stability of the rest predictions while retaining the benefits of

341 SMG-based control (namely, robust classification of motion end-states and the ability to enable

342 proportional positional control). One possibility could be the implementation of a hybrid control

343 system in which EMG signals serve as the input for a binary classifier to predict rest or motion.

344 Once a deviation from rest is detected, then SMG could be used for classifying the intended

345 grasp and completion level.

346 One limitation that should be acknowledged about this study is that only a single

347 participant was involved, so the findings should not be generalized without additional study in a

348 larger population of individuals with transhumeral limb loss. Additionally, the modality used for

349 prompting the subject's transitions between motion and rest states was inconsistent (i.e., auditory

350 cues for SMG, visual cues for EMG). The visual cues were used as a matter of convenience, as

351 the subject collected the EMG data from himself. Reaction times for auditory cues are typically

352 shorter than those for visual cues [38,39], with a commonly-reported difference of approximately

$35340 \mathrm{~ms}$ [40]. We do not believe a difference of this magnitude would have any bearing on the

354 results. Furthermore, both the EMG and SMG data were collected under ideal settings with no

355 external sources of noise that would likely arise during real-world prosthesis use (e.g., changes in 
medRxiv preprint doi: https://doi.org/10.1101/2020.12.23.20248489; this version posted December 26, 2020. The copyright holder for this preprint (which was not certified by peer review) is the author/funder, who has granted medRxiv a license to display the preprint in perpetuity.

It is made available under a CC-BY-NC-ND 4.0 International license .

356 skin impedance from perspiration, shifts in the relative positions of the residual limb and sensors

357 due to arm movement or socket loading). These problems are known to occur with our subject's

358 clinically prescribed EMG prosthesis, so he typically has only six motion classes enabled.

359 Predicting 11 motion classes would be extremely difficult for him under normal circumstances.

360 Although we are currently undertaking work to formally assess the use of SMG to control

361 prostheses in real-world settings, we anticipate that similar issues may arise that would reduce

362 the number of achievable motion classes. Additionally, it should be reiterated that the SMG data

363 were obtained using a clinical ultrasound system with an array transducer. In the future, we plan

364 to use single-element transducers with low-power electronics that could be integrated into a

365 standalone prosthesis socket. Although our prior work suggests that classification accuracy is not

366 reduced with a sparse sensing strategy [41], this has not yet been confirmed in individuals with

367 limb loss. Finally, the sampling rate for EMG was considerably higher than for SMG, so more

368 frames of EMG data were available to train the classifier. However, the use of a smaller training

369 data set for SMG did not appear to have a detrimental effect, as the classification accuracy was

370 higher for SMG than EMG in most circumstances.

\section{Conclusion}

373 This exploratory study demonstrated that prediction of 11 hand and finger motions was

374 possible for an individual with transhumeral limb loss using SMG. Despite the individual's lack

375 of a forearm, he was able to generate distinctive muscle activation patterns in his upper arm that

376 could be successfully detected and classified using both SMG and EMG. The classification

377 accuracy was typically higher for SMG than EMG, regardless of the method used to train the 
medRxiv preprint doi: https://doi.org/10.1101/2020.12.23.20248489; this version posted December 26, 2020. The copyright holder for this preprint (which was not certified by peer review) is the author/funder, who has granted medRxiv a license to display the preprint in perpetuity.

It is made available under a CC-BY-NC-ND 4.0 International license .

378 classifier. These findings suggest that SMG may eventually be a viable prosthesis control

379 strategy, even for individuals with transhumeral limb loss.

380

381 Acknowledgements

The authors would like to thank Dr. Jaimie Shores for sharing his expertise regarding

383 amputation procedures and targeted muscle reinnervation.

\section{References}

386 1. Biddiss EA, Chau TT. Upper limb prosthesis use and abandonment: a survey of the last 25

387 years. Prosthet Orthot Int. 2007;31(3):236-57.

2. Biddiss E, Chau T. Upper-limb prosthetics: critical factors in device abandonment. Am J Phys Med Rehabil. 2007;86(12):977-87.

4. Vu PP, Chestek CA, Nason SR, Kung TA, Kemp SWP, Cederna PS. The future of upper

3. Smail LC, Neal C, Wilkins C, Packham TL. Comfort and function remain key factors in upper limb prosthetic abandonment: findings of a scoping review. Disabil Rehabil Assist Technol. 2020 Mar 19;1-10. extremity rehabilitation robotics: research and practice. Muscle Nerve. 2020 Jun 1;61(6):708-18.

401 7. Kong YK, Hallbeck MS, Jung MC. Crosstalk effect on surface electromyogram of the

5. Clancy E, Morin EL, Merletti R. Sampling, noise-reduction and amplitude estimation issues in surface electromyography. J Electromyogr Kinesiol. 2002;12(1):1.

6. Graimann B, Dietl H. Introduction to upper limb prosthetics. In: Farina D, Jensen W, Akay M, editors. Introduction to Neural Engineering for Motor Rehabilitation. Hoboken, NJ: John Wiley \& Sons, Inc.; 2013. p. 267-90.

403 8. van Duinen H, Gandevia SC, Taylor JL. Voluntary activation of the different compartments 404 of the flexor digitorum profundus. J Neurophysiol. 2010;104(6):3213-21.

405 9. van Duinen H, Yu WS, Gandevia SC. Limited ability to extend the digits of the human 406 hand independently with extensor digitorum. J Physiol. 2009;587(20):4799-810. 
10. McIsaac TL, Fuglevand AJ. Motor-unit synchrony within and across compartments of the human flexor digitorum superficialis. J Neurophysiol. 2007;97(1):550-6.

11. Hargrove LJ, Scheme EJ, Englehart KB, Hudgins BS. Multiple binary classifications via linear discriminant analysis for improved controllability of a powered prosthesis. IEEE Trans Neural Syst Rehabil Eng. 2010;18(1):49-57.

12. Kuiken TA, Miller LA, Turner K, Hargrove LJ. A Comparison of Pattern Recognition Control and Direct Control of a Multiple Degree-of-Freedom Transradial Prosthesis. IEEE J Transl Eng Health Med. 2016;4:1-8.

13. Hargrove LJ, Miller LA, Turner K, Kuiken TA. Myoelectric Pattern Recognition Outperforms Direct Control for Transhumeral Amputees with Targeted Muscle Reinnervation: A Randomized Clinical Trial. Sci Rep. 2017 Oct 23;7(1):13840.

14. Resnik L, Huang HH, Winslow A, Crouch DL, Zhang F, Wolk N. Evaluation of EMG pattern recognition for upper limb prosthesis control: a case study in comparison with direct myoelectric control. J NeuroEngineering Rehabil. 2018;15(1):23.

15. Resnik LJ, Acluche F, Borgia M, Cancio J, Latlief G, Phillips S, et al. EMG pattern recognition compared to foot control of the DEKA Arm. PLOS One. 2018;13(10):e0204854.

16. Resnik L, Acluche F, Borgia M, Latlief G, Phillips S. EMG Pattern Recognition Control of the DEKA Arm: Impact on User Ratings of Satisfaction and Usability. IEEE J Transl Eng Health Med. 2019;7:2100113.

17. Tenore FV, Ramos A, Fahmy A, Acharya S, Etienne-Cummings R, Thakor NV. Decoding of individuated finger movements using surface electromyography. IEEE Trans Biomed Eng. 2009 May;56(5):1427-34.

18. Cipriani C, Antfolk C, Controzzi M, Lundborg G, Rosen B, Carrozza MC, et al. Online myoelectric control of a dexterous hand prosthesis by transradial amputees. IEEE Trans Neural Syst Rehabil Eng. 2011;19(3):260-70.

19. Khushaba RN, Kodagoda S, Takruri M, Dissanayake G. Toward improved control of prosthetic fingers using surface electromyogram (EMG) signals. Expert Syst Appl. 2012;39(12):10731-8.

20. Al-Timemy AH, Bugmann G, Escudero J, Outram N. Classification of finger movements for the dexterous hand prosthesis control with surface electromyography. IEEE J Biomed Health Inform. 2013;17(3):608-18.

21. Franzke AW, Kristoffersen MB, Bongers RM, Murgia A, Pobatschnig B, Unglaube F, et al. Users' and therapists' perceptions of myoelectric multi-function upper limb prostheses with conventional and pattern recognition control. PLOS One. 2019;14(8):e0220899. 
22. Resnik LJ, Acluche F, Klinger SL. User experience of controlling the DEKA Arm with EMG pattern recognition. PLOS One. 2018;13(9):e0203987.

23. Shi J, Chang Q, Zheng Y-P. Feasibility of controlling prosthetic hand using sonomyography signal in real time: preliminary study. J Rehabil Res Dev. 2010;

24. Chen X, Zheng Y-P, Guo J-Y, Shi J. Sonomyography (SMG) Control for Powered Prosthetic Hand: A Study with Normal Subjects. Ultrasound Med Biol. 2010;36(7):107688.

25. Yang X, Chen Z, Hettiarachchi N, Yan J, Liu H. A Wearable Ultrasound System for Sensing Muscular Morphological Deformations. IEEE Trans Syst Man Cybern Syst. 2019;1-10.

26. Yang X, Yan J, Fang Y, Zhou D, Liu H. Simultaneous prediction of wrist/hand motion via wearable ultrasound sensing. IEEE Trans Neural Syst Rehabil Eng. 2020;

27. Sikdar S, Rangwala H, Eastlake E, Hunt I, Nelson A, Devanathan J, et al. Novel method for predicting dexterous individual finger movements by imaging muscle activity using a wearable ultrasonic system. IEEE Trans Neural Syst Rehabil Eng. 2014;22(1):69-76.

28. Akhlaghi N, Baker CA, Lahlou M, Zafar H, Murthy KG, Rangwala HS, et al. Real-time Classification of Hand Motions using Ultrasound Imaging of Forearm Muscles. IEEE Trans Biomed Eng. 2016;63(8):1687-98.

29. Zheng YP, Chan MMF, Shi J, Chen X, Huang QH. Sonomyography: Monitoring morphological changes of forearm muscles in actions with the feasibility for the control of powered prosthesis. Med Eng Phys. 2006;28(5):405-15.

30. Hettiarachchi N, Ju Z, Liu H. A New Wearable Ultrasound Muscle Activity Sensing System for Dexterous Prosthetic Control. In: 2015 IEEE International Conference on Systems, Man, and Cybernetics. 2015. p. 1415-20.

31. Baker CA, Akhlaghi N, Rangwala H, Kosecka J, Sikdar S. Real-time, ultrasound-based control of a virtual hand by a trans-radial amputee. In: Conference Proceedings of the IEEE Engineering in Medicine and Biology Society. 2016. p. 3219-22.

32. Dhawan AS, Mukherjee B, Patwardhan S, Akhlaghi N, Diao G, Levay G, et al. Proprioceptive Sonomyographic Control: A novel method for intuitive and proportional control of multiple degrees-of-freedom for individuals with upper extremity limb loss. Sci Rep. 2019;9(1):9499.

33. Engdahl S, Dhawan A, Bashatah A, Diao G, Mukherjee B, Monroe B, et al. Individuals With Upper Limb Loss Require Minimal Training to Achieve Robust Motion Classification Using Sonomyography [Internet]. Research Square [Preprint]; 2020 [cited 2020 Nov 9]. Available from: https://doi.org/10.21203/rs.3.rs-65415/v1 
medRxiv preprint doi: https://doi.org/10.1101/2020.12.23.20248489; this version posted December 26, 2020. The copyright holder for this preprint (which was not certified by peer review) is the author/funder, who has granted medRxiv a license to display the preprint in perpetuity.

It is made available under a CC-BY-NC-ND 4.0 International license .

34. Patwardhan S, Dhawan AS, Mukherjee B, Alzamani M, Joiner WM, Sikdar S. Evaluation of the Role of Proprioception During Proportional Position Control Using Sonomyography: Applications in Prosthetic Control. In: 2019 IEEE 16th International Conference on Rehabilitation Robotics (ICORR). 2019. p. 830-6.

35. Yang X, Sun X, Zhou D, Li Y, Liu H. Towards Wearable A-Mode Ultrasound Sensing for Real-Time Finger Motion Recognition. IEEE Trans Neural Syst Rehabil Eng. 2018;26(6):1199-208.

36. Huang Y, Yang X, Li Y, Zhou D, He K, Liu H. Ultrasound-Based Sensing Models for Finger Motion Classification. IEEE J Biomed Health Inform. 2018 Sep;22(5):1395-405.

37. Kuiken TA, Li G, Lock BA, Lipschutz RD, Miller LA, Stubblefield KA, et al. Targeted muscle reinnervation for real-time myoelectric control of multifunction artificial arms. J Am Med Assoc. 2009;301(6):619-28.

38. Jose S, Gideon Praveen K. Comparison between auditory and visual simple reaction times. Neurosci Med. 2010;2010.

39. Jain A, Bansal R, Kumar A, Singh KD. A comparative study of visual and auditory reaction times on the basis of gender and physical activity levels of medical first year students. Int $\mathbf{J}$ Appl Basic Med Res. 2015;5(2):124-7.

40. Elliott R. Simple visual and simple auditory reaction time: A comparison. Psychon Sci. 1968;10(10):335-6.

41. Akhlaghi N, Dhawan A, Khan A, Mukherjee B, Diao G, Truong C, et al. Sparsity Analysis of a Sonomyographic Muscle-Computer Interface. IEEE Trans Biomed Eng. 2019;67(3):688-96.

\section{Supporting Information}

\section{S1 Dataset. Full datasets collected using SMG and EMG.}

